PROBLEMS

OF MANAGEMENT IN THE $21^{\text {st }}$ CENTURY Vol. 16, No. 2, 2021

\title{
CONTROLLING IN ERA OF INDUSTRY 4.0: OPPORTUNITIES FOR BUSINESSES IN THE FIELD OF THE INTRODUCTION OF NEW TECHNOLOGIES
}

\author{
Pavol Zahoran, Ondrej Zizlavsky \\ Brno University of Technology, Czech Republic \\ E-mail: Pavol.Zahoran@vutbr.cz, Ondrej.Zizlavsky@vut.cz
}

\begin{abstract}
Automation, robotics, Internet of Things and Big Data are currently a big challenge for businesses. However, they can also be a great opportunity. One of the corporate areas where new technologies can be used is controlling. In this research, the issue is narrowed down to the impact of new technologies on Enterprise Resource Planning (ERP) systems of companies, which are a basic tool of controlling in companies. The research analyses the possibilities of integrating elements of Industry 4.0 with ERP systems and the possibility of using data for corporate controlling. For this purpose, a literature review was carried out and gained results were further analysed according to the defined criteria. The outcome of the literature review is an essential current state analysis of the impact of new technologies on corporate ERP systems with regard to the company's controlling processes. This paper serves as a very first step in designing a systematic research study in area of controlling 4.0.
\end{abstract}

Keywords: automation, controlling, Enterprise Resource Planning (ERP), Industry 4.0, management control, management accounting

\section{Introduction}

While new technologies are a tool for consumers to increase their comfort, for businesses it is a key issue. For companies, the introduction of new technologies plays a role both on the revenue side and on the costs side. On the revenue side, in today's highly competitive markets, those companies that can launch a product that has a unique feature, or even a completely revolutionary product, are more likely to be successful (Kotler \& Caslione, 2009). This aspect mainly concerns final producers, but it can also play a role in custom manufacturing companies. A company that manages to launch such a product may then experience high-margin sales for a period of time until the market responds and competing companies offer customers alternative products (Kašík \& Havlíček, 2015). The period of time for which a company is able to benefit from its competitive advantage due to its technological advantage has been shortening in recent years (Zuzák \& Königová, 2009). The main reason is the availability of information and thus the higher speed at which the market is able to respond. Large technology companies, manufacturers of premium car brands or even technology start-ups, operate on this principle. There are a number of negative cases when large technology companies have not captured market developments and it has become almost fatal for them. Probably the best known is the case of Nokia.

As for smaller companies, and companies that are more engaged in custom manufacturing, the norms mentioned above apply to them to a much lesser extent. When they are one of the suppliers for another company, in principle they cannot significantly influence the price, especially not today in highly competitive conditions, and need to add or expand global mar- 
kets (Veber \& Srpová, 2012). On the other hand, they can maximize their profits by producing the same product at a lower cost. However, this also applies to large companies which are

PROBLEMS OF MANAGEMENT IN THE $21^{\text {st }}$ CENTURY Vol. 16 , No. 2, 2021 constantly looking for ways to reduce costs. The introduction of new technologies plays a key role in reducing costs. However, the introduction of a new technology precedes the phase when the company must be able to identify which costs it wants to reduce and calculate how much the introduction of new technology will cost and what the real costs savings will be. Following the introduction of the new technology, the best companies monitor whether the goal has been achieved or what the deviations are. In order to be able to identify the area in which the company wants to reduce costs, it must have the right source of data, which are currently ERP systems (Songyue \& Shangyang, 2019). Furthermore, it must have an employee - a controller who is able to identify this area and who is able to implement the project of introducing new technology. Last but not least, the optimal scenario is when the manufacturer of the new technology is able to integrate its product into the company's ERP system so that the controller can subsequently monitor the costs of the new technology. The success of the whole project therefore depends on the quality of all three components, ERP system - controller - integration of new technology into the corporate system. All three are closely interconnected and the controlling, i.e., controller plays key roles. Due to the above mentioned, the importance of controlling is increasing and the position of controllers within corporate structures is gradually changing over time.

It follows that the topic of the impact of new technologies on controlling is crucial for companies. And it's not just cost controlling. New technologies are also being reflected in sales, marketing and logistics, and controlling should be carried out here as well. The better technology is available to assist controlling, the bigger is the assumption that it will be performed with higher accuracy.

The research aim was to conduct an analysis of the current state regarding the impact of new technologies on ERP systems of companies, or even their integration with ERP systems in relation to corporate controlling. The research provided theoretical background of the influence of new technologies on the managerial discipline of Controlling. The article serves as an elemental framework for further scientific research.

The analysis focuses on the ERP system of the enterprise as the primary source of data for controlling purposes, and it also takes into consideration that the ERP is the central tool of corporate controlling. The analysis also includes a description of the current state of Industry 4.0 in the Czech Republic with regard to the definition of Industry 4.0 and its various concepts within the corporate sphere. Furthermore, the development of the management discipline of controlling is described with the aim of pointing out that the era of Industry 4.0 represents a new development stage and also a great opportunity for controlling.

\section{Research Methodology}

The research was carried out in three following stages.

1. Planning the review

2. Conducting the review (data collection and analysis)

3. Data synthesis

Planning the Review

This stage involves the definition of the following keywords: "Controlling", "Management Control", "Management Accounting", "ERP", "Industry 4.0", "Automation", "Innovation". When searching for relevant literary sources, the keywords "Industry 4.0", "Automation" 
Pavol ZAHORAN, Ondrej ZIZLAVSKY. Controlling in era of industry 4.0: opportunities for businesses in the field of the introduction of new technologies

OF MANAGEMENT IN THE $21^{\text {st }}$ CENTURY Vol. 16, No. 2, 2021

and "Innovation" were used in their Czech translation, as the following research is focused on analysing the impact of new technologies within companies operating in the Czech Republic. The basic search engine was Google Scholar which provides a relatively wide range of professional resources. Subsequently, the found sources were reduced according to the following criteria:

- Resources available in the Elsevier Scopus and Thomson Reuters Web of Science databases

- Resources in English / Czech language

- Resources containing at least two keywords in the abstract or keywords

The period of resource age 2008-2021 was set for the chapters analysing the development of Industry 4.0 and the development of Controlling. For the chapters analysing the influence of new technologies on controlling the period was set to 2015-2021.

\section{Data Collection and Analysis}

As part of the data collection, the available resources were further reduced as follows. For the chapters Industry 4.0 and Development of controlling, only sources that directly deal with the given topic were selected. For professional books, the Introduction and Content of books were assessed. For professional articles, an abstract containing the given keyword. For the Controlling and Industry 4.0 sections, a search in the Elsevier Scopus and Thomson Reuters Web of Science databases was used. These databases were selected due to their advanced web search mechanisms, high volume of indexed publications, and proven relevance. As a criterion for inclusion of the article in the next search, the abstract of the article had to contain a combination of two keywords. Subsequently, abstracts of selected articles were read, and it was assessed whether the content of the article is in line with the aim of this research.

After collecting an initial set of studies, all articles in the sample were analysed, data was extracted and documented independently by the researchers and then the findings were compared and reconciled. When reviewing the findings, the researchers applied strict criteria to assess the quality of published papers. The criteria include: country of research, size and quality of research sample in terms of representation, the strength of the conclusions, and the link to objectives of our research project in the Czech Republic.

\section{Data Synthesis}

This part of the research is the primary value-added product of a review process. In a study a synthesis is used for design of future research in area of impact of new technologies on a managerial discipline controlling.

\section{Research Results}

\section{Industry 4.0}

Before describing the impact of the Fourth Industrial Revolution on controlling, it is necessary to clarify what Industry 4.0 represents. Since the Technology Fair in Hanover in 2013 when the concept of Industry 4.0 was first publicly presented, a number of texts have been published on this topic, which do not always agree on what Industry 4.0 means.

Industry 4.0 can be characterized as a concept related to digitization and automation, whose key pillars are cyberphysical systems (CPS), Internet of Things (IoT), Internet of Servic- 
es (IoS), system integration and big data analysis (Big Data). The concept presented in Hanover describes the gradual emergence of so-called "smart" factories, where previously automated but isolated production units will be connected. The Internet plays a key role, and the concept envisages the emergence of new global networks. In "smart" factories, cyberphysical systems will play a key role; they will be capable of sharing and exchanging information with each other, capable of autonomous decision-making, configuration and subsequent control. Thanks to the Internet, the hitherto isolated automated elements will be interconnected and integrated into a complex, which in many cases will exceed the boundaries of the company. Mařík (2015) pointed out, in this detail the concept of Industry 4.0 differs from automation, or simply the connection of a machine to the Internet, and therefore should not be confused with the concept of automation. Ivanov et al. (2021) describe the smart factories of Audi and Siemens, which meet the exact definition of Industry 4.0, but also point out the ambiguity in understanding the concept of Industry 4.0.

In the Czech Republic, a strategy for the Czech Republic's approach to Industry 4.0, called the Industry 4.0 Initiative, was formulated in 2015 under the auspices of the Ministry of Industry and Trade. This relatively extensive document defines the concept of Industry 4.0, further analyses the current situation in the Czech Republic, and also identifies individual areas in which the state should take steps in the future to create suitable conditions for the implementation of the new concept. Specifically, it is about building ICT infrastructure and ensuring its security, places new requirements on applied research and education, analyses the readiness of the legal environment, and also analyses the resources needed for the implementation of Industry 4.0.

The question is what the Czech government has managed to implement in almost 6 years since the formulation of the strategy. In any case, it is certain that by being one of the most industrialized countries in the world, it will be crucial for Czech Republic business leaders to be responsive in how we deal with Industry 4.0. In the public sphere, discussions have been resonating for a long time about the need to change the model of the Czech economy to an economy with higher added value. Industry 4.0 is the way to achieve this goal, and the more successful we are in implementation, the more competitive we will be in global markets.

\section{Development of Controlling}

In order to better understand the trends and challenges the current controlling model is facing in the era of Industry 4.0, it is necessary to look at least briefly at its historical development. Controlling is influenced, like other fields or scientific disciplines, especially by major social and technological changes. This is not a historical excursion, but rather a list of the most important socio-technological changes that have influenced controlling. Based on this, it is possible to better understand the current state of controlling and understand controlling in the era of Industry 4.0 as another necessary development stage.

The first mention of controlling comes from the United States of America (USA) from the end of the 19th century, when the first American companies, especially railway and industrial companies, introduced the position of controller into their organizational structures (Kutác \& Janovská, 2012). In principle, this was one of the consequences of the invention of the telegraph and the great expansion of the railways, which led to the interconnection of hitherto relatively distant markets and the emergence of large companies that already required different approaches to financial management. Another milestone in the development of controlling is the 1920s and 1930s, when the Great Depression forced American companies to better manage their costs. Already at this time, companies began to plan costs and compare actual costs with budgeted ones. This made it possible to identify deviations and better plan future costs. In the 1930s, the Controller's Institute of America was founded in the USA (Psárska et al., 2016),

\author{
PROBLEMS \\ OF MANAGEMENT \\ IN THE $21^{\text {st }}$ CENTURY \\ Vol. 16, No. 2, 2021 \\ 125
}


Pavol ZAHORAN, Ondrej ZIZLAVSKY. Controlling in era of industry 4.0: opportunities for businesses in the field of the introduction of new technologies

PROBLEMS

OF MANAGEMENT IN THE $21^{\text {st }}$ CENTURY Vol. 16, No. 2, 2021

which today exists as the Financial Executives Institute (FEI). It is a professional association whose members are financial directors, accountants, controlling staff, but also, for example, treasurers of individual companies.

An important period for the further development of controlling is the post-war period of the $60 \mathrm{~s}$ and $70 \mathrm{~s}$ of the twentieth century, when controlling was introduced in Europe thanks to branches of American companies. It is also a period of economic stagnation, when companies focus again on improving cost management, but also a period of gradual introduction of information technology, which significantly changed the possibilities of companies in the field of controlling.

In the Czech Republic (Czechoslovakia), the first mentions of controlling in Bat'a's plants can be observed as early as the 1930s. At that time, controlling activities in Bata's companies focused on cost management, while the outputs of controlling activities were the reports used by managers to make further decisions. At that time, it was a sophisticated system of planning and monitoring costs, but also a well-functioning system of budgeting and calculations (Kutáč \& Janovská, 2012). The further development of controlling in the Czech Republic can be observed in the 1990s, after the fall of socialism. The return to controlling in this period is due to the branches of foreign companies, which began operating in the Czech Republic after the Velvet Revolution, but gradually adopted by the owners and managers of Czech companies, especially medium and large ones. Today, in principle, the concept prevails in which controlling is divided into strategic and operational. According to Havlíček (2011), deviations in operational controlling are evaluated on the basis of quantitative parameters, while in strategic control it is partly on the basis of quantitative ones, but especially on the basis of qualitative parameters.

\section{Controlling and Industry 4.0}

The situation on world markets is not easy for businesses. Today's global companies operate in different parts of the world, while the territories can vary significantly. There are many factors, starting with language, culture and national habits, the local legal system, currency, the purchasing power of companies and the population, and last but not least, the level of infrastructure that the state has at its disposal. The consequence of globalization and the rapid technological development that we can observe in recent years is the fact that socio-economic changes are "spilling over" from one territory to other regions of the world much faster (Častorál, 2008). We are witnessing a relatively dynamic development and companies doing business in several regions of the world must be almost constantly on the alert. Due to this reason, today, the established controlling is a must for large international companies. Písař and Mazo (2020) stated that globalization and Industry 4.0 bring new challenges for companies. Companies are forced to use a flexible management approach, which consists of constantly monitoring and re-evaluating processes in order to increase the value of the company. One of the tools is controlling. There is also a significant change in the position of the controller (controlling departments) within individual companies (Storm, 2018).

The company's ERP system becomes the main controlling tool, as the primary source of an inexhaustible amount of company data. The task of controllers is to collect, analyse and interpret this data for management purposes. It is obvious that each controller uses the ERP system for controlling in a different way, so further research will investigate what are the current trends in the development of ERP systems in the field of controlling.

\section{ERP systems: current state and actual trends}

Many companies currently offer ERP solutions globally but also on the Czech market. In recent years, a relatively rapid growth in demand for ERP systems can be observed. Many, 
especially small and medium-sized enterprises, realize that it is more advantageous to have one complex system than more fragmented and isolated systems. Thanks to strong competition on

PROBLEMS OF MANAGEMENT IN THE $21^{\text {st }}$ CENTURY Vol. 16 , No. 2, 2021 the supply side, ERP systems are more affordable for smaller companies, and this plays a significant role today. Due to the fact that the biggest innovators in the field of controlling and ERP systems are large companies, the following text will be devoted only to the analysis of large companies and their suppliers of ERP systems.

As already mentioned, the global ERP market has been growing steadily for a long time. The outlook for the coming years also predicts further stable growth with an average annual rate of $8.1 \%$ (Biel, 2020). In the segment of solutions for large companies, SAP and Oracle are the largest players in the global market. Both companies offer robust systems suitable especially for large companies and multinational corporations. This is mainly due to the fact that the ERP systems of these companies are unnecessarily large in terms of scalability of functions for small and medium-sized businesses. Another factor is the maintenance and support of the system, which is expensive for most of smaller companies. However, it is true that in recent years, SAP and ORACLE have also focused on medium and small companies, to which they offer modified versions of their solutions. This trend is related to the growing demand for ERP solutions on the part of small and medium-sized enterprises, which has already been discussed.

Regarding the situation in the Czech Republic, in the segment of large companies, the situation on the ERP market is similar to that in the world, i.e., the two suppliers are the dominant providers of ERP solutions. This is mainly due to the fact that a significant part of large companies in the Czech Republic are subsidiaries of multinational corporations. The Czech Republic lags behind Germany and Austria in the number of ERP systems in companies with more than 250 employees, but the situation is comparable to Poland and the EU average (Sodomka \& Klčová, 2018).

The most significant trends in the ERP market are the transition to cloud solutions and the Internet of Things, which is directly related to the concept of Industry 4.0. According to Majstorovic et al. (2020), data is a key tool now for companies for planning and controlling and can only be used if it is error-free, current and available. One of the tools to achieve this is a cloud solution for data storage and data sharing. However, the transition to the cloud is not as fast as expected, which is mainly due to two factors. First, many companies are afraid to entrust the management of their data to third parties. The main concern of companies is a certain loss of control over data, to which is added a concern about data security. The second factor is that the costs of data management in the Czech Republic are lower compared to the USA or Western Europe, so one of the main advantages of the cloud is partially blurred, and that is the costs of system administration and maintenance (Křriž \& Zajíc, 2018).

The second major trend is the Internet of Things. In the previous chapter, it was described that the Internet of Things is one of the key pillars of Industry 4.0. It is related to the possibility of connecting, for example, a machine or an entire production line to the Internet and thus sharing various data. Suppliers of ERP systems must not ignore this trend, because there are requirements from companies to connect machinery and equipment with ERP systems (Kříž \& Zajíc, 2018). This trend is also important for our further research, as it will be examined in detail what are the specific requirements of companies towards ERP vendors. The thesis will examine for which types of companies the collection and connection of data with ERP is important, how the connection with ERP occurs and whether the data are used for controlling purposes.

\section{Controlling and ERP systems}

Nowadays, no large international company can do its business without a well-established controlling process. All large suppliers of ERP solutions offer a controlling module in their programs. Due to the fact that the term controlling is almost no longer used today, especially in 
Pavol ZAHORAN, Ondrej ZIZLAVSKY. Controlling in era of industry 4.0: opportunities for businesses in the field of the introduction of new technologies

OF MANAGEMENT IN THE $21^{\text {st }}$ CENTURY Vol. 16, No. 2, 2021

the British-American area (Kutáč \& Janovská, 2012), some ERP suppliers offer a controlling module under other names, such as Management Accounting.

The reasons why large companies today can no longer do their businesses without controlling have been mentioned in the previous text of this work. However, let's review them once again and develop these a little bit more. Large companies impose new requirements on ERP system suppliers as the results of the following development trends.

The first trend to be mentioned are the economic and social differences of the individual territories where international companies operate. Large companies offer their products in markets that differ in purchasing power, shopping behaviour, culture or even religion. For this reason, companies must constantly monitor developments in individual territories (Storm, 2014). The task of controlling is to monitor the deviations of the planned goals from the actually achieved results. Another factor, due to which the company must have established controlling, is the current interconnection of individual territories. Due to globalization and new technologies, the time during which an event moves from one territory to other territories has been significantly reduced. A shining negative example is the current coronavirus crisis. The virus had spread around the world in a relatively short period of time; it also had a significant impact on large companies, which in many cases have production capacity located in Asia. The supply chains have been severely disrupted and many multinational companies are currently having problems supplying products. On the other hand, it is necessary to recognize that the current crisis is unprecedented, and no controlling department could have predicted it. The need for controlling is also reflected in the fact that today's large companies have a diversified product portfolio to eliminate corporate risk. The whole thing is complicated by the fact that the individual divisions of the company can be completely independent of each other and offer their products worldwide through their specific sales channels. Thus, let's say a line controlling system is created, while controlling is performed both at the level of the division itself and subsequently also at the central level.

It is not easy to set up a controlling system for large companies, which usually have complicated structures and are influenced by the factors mentioned above. An ERP system plays a key role here and can provide relevant outputs for decision-making by the company's management. The ERP has to be a robust system, which is offered by only a few companies on the market. One of them is the German software company SAP, which offers the FICO (Finance - Controlling) module in its ERP system. The controlling module, or managerial accounting module, consists of the following six components (Jones \& Burger, 2009):

- Cost Elements - cost management based on cost elements; it basically copies the chart of accounts and the system of accounts in the company

- Cost Centres - cost monitoring by cost centres; costs are assigned to the individual centres where the costs were incurred (for example, the Sales, Admin, Service, etc.)

- Profit Centres - allows monitoring the profitability of individual divisions of the company or its other lower organizational levels

- Internal Orders - allows monitoring and managing the costs of individual short-term projects, such as marketing campaigns

- Profitability Analysis - evaluating the profitability of individual products; allows monitoring and comparing the profitability of a given product, for example in a specific territory or for individual customer groups

- Product Costing - allows a company to control the production costs of a specific product

The Controlling (CO) module in SAP takes all the information from the Finance (FI) module. Each accounting operation is recorded in the company's accounting, but it also appears in the $\mathrm{CO}$ module, where it is used to compile various reports. The above components of the $\mathrm{CO}$ 
module allow the compiling of a wide range of different reports and thus monitor and manage costs in all areas of a large company.

One of the goals of further research will be a detailed analysis of the requirements of large companies towards ERP system suppliers with regard to the compilation of controlling reports. It can be assumed that controlling staff in individual large companies make various demands on ERP vendors, such as SAP. In this way, requirements from all over the world are collected by the ERP supplier, and it is up to the developers to evaluate the requirements and implement them as a solution in their programs. Based on researchers' personal experience in a multinational company, this is not an easy task for the development department. The point is that while the requirements are on the one hand very diverse with a relatively wide scope, it also often happens that the requirements are contradictory. Although large ERP systems can absorb many new functions and large ERP vendors can also customize their products, there still must be standardized functions that will provide a global solution for companies. Fortunately, the development in this direction is moving relatively fast and ERP suppliers are able to satisfy the requirements of their customers thanks to new technologies.

\section{The current role and position of controller in the company}

One of the important factors in changing the position of controllers in current companies are new technologies. They place completely new requirements on controllers, especially in terms of so-called technical skills. Other reasons for the change of position have already been described in the previous text. It is a gradual development in the markets, which, thanks to globalization and trade liberalization, has enabled the emergence of large companies operating in various parts of the world. Combined with the fact that companies currently operate in a relatively dynamic and rapidly changing environment, the controlling is gaining an importance and thus the role and position of controllers within companies is also changing (Storm, 2018).

First of all, it is necessary to distinguish the position of controllers within the organizational structures of British-American and European companies, especially companies in the DACH region (Germany, Austria, Switzerland). According to Šoljaková (2012), while at British-American companies the controller is usually in charge of accounting and taxes in addition to controlling, at companies from the German-speaking area the position of the controller is within the company as a separate position. In these companies, the controller also cooperates with the accounting department, but is not directly responsible for accounting and related reporting to external bodies. His primary task is the preparation of statements for internal use and documents for decision-making by the company's management. However, it should be mentioned that in reality the two mentioned models are mixed in companies, and it is also necessary to emphasize that there is no precise definition of how the competences of the controller within the company should be precisely defined. In any case, what both models have in common is a fundamental change in the position of controllers compared to the position in the last century, especially in these areas.

- Definition of competencies and responsibilities within companies

- Requirements for professional and skill profile

As for the first area, at the same time as the importance of controlling in corporate management gradually increased, the position of controllers also changed. Whereas, in the last century the controller was more like a supporting body in the managerial decision-making process, today the controller participates in managerial decisions, both strategic and operational. As a result, the responsibility of controllers has also increased, although here the situation varies from company to company depending on how strong the position of the controller is within 
Pavol ZAHORAN, Ondrej ZIZLAVSKY. Controlling in era of industry 4.0: opportunities for businesses in the field of the introduction of new technologies

OF MANAGEMENT IN THE $21^{\text {st }}$ CENTURY Vol. 16, No. 2, 2021

the company (Lazar, 2012). In any case, he is definitely no longer just an assistant manager; in many cases it is an equal position. One of the key moments of the change was the economic crisis of 2008-2009, when it significantly strengthened the role of financial directors and controlling departments. Many companies have realized the importance of risk management and having developed alternative development scenarios. Another difference in the position of the controller is that today's controller must cooperate with all departments of the company; its scope is not limited only within the finance department.

Due to the rapid development of ICT technologies, the need to cooperate with other departments and, last but not least, the fact that the controller must have a relatively broad view, the requirements for the professional and skill profile of current controllers have changed significantly. An interesting survey was conducted by Faltejsková and Dvořáková (2011), which compared the requirements for expertise and skills of controllers on job portals before the economic crisis of 2008-2009 and after the crisis in 2011. The most significant changes were detected in increased requirements for practice, in the ICT knowledge, and in advanced knowledge of MS Excel. This shows that companies are looking for experienced controllers who can work well with new technologies and data. The survey was conducted ten years ago and the development in ICT has made considerable progress since then, therefore it can be assumed that these requirements have become even more important.

Today's large companies demand experienced controllers with a relatively wide view, excellent knowledge of ICT technologies and also excellent so-called soft skills. Soft skills, such as personality prerequisites, are very important today, because as today's position of controller already extends to other departments of the company, so it must be a person who can communicate with colleagues from other departments who often look at the same thing from a different perspective. Today's controller must be able to defend his recommendations for management, he must have the ability to resist pressure from superiors, but also subordinates, and last but not least, he must have the ability of analytical and global thinking (Faltejsková \& Dvořáková, 2011). An interesting but concise definition of the skill requirements of current controllers is presented by Papánek (2015, p.11), according to which a good controller "should have knowledge of processes in the company at the level needed to understand economic flows in the company, especially knowledge and overview of where they are generated, at what costs and where the added value is generated, including the connections, context and synergies between them." The above shows a fundamental change in the requirements placed on current controllers compared to those of the last century.

However, the subject of the following scientific research is not to examine general trends, but to narrow the issue and focus only on changes in the requirements associated with new technologies. The controllers have a wealth of data and information available in the ERP and it is up to them as to how and which data they process, how they evaluate them and how they subsequently develop and present them as a recommendation for management. The research will examine in detail what technological changes (such as various applications) controllers today use to process and interpret the data. It can be assumed that in order to better interpret the data, controllers make different demands on the suppliers of their ERP programs, or on external companies that develop different applications. Furthermore, the current trends in this area will be examined and an effort will be made to draw a general conclusion from the research, or even to quantify the benefits of using new technologies in controlling.

Integration of external technologies with ERP systems

The third area which the following research will examine is the integration of ERP systems with surrounding technologies. In this sense, the integration can be found in three areas. 
a. Integration of MES (Manufacturing Execution Systems) systems with ERP

b. Integration related to IoT (Internet of Things)

c. Integration of external applications with ERP

The integration of MES systems with ERP is a relatively broad issue. The concept of MES systems began to appear in business practice in the 1980s, followed by a major boom in the 1990s. The MES, similar to ERP, does not have a precisely defined form in terms of functionality (Fatima et al., 2020). Many companies offer MES systems on the global but also on the Czech market. Due to the technological progress that has taken place since the 1980s, today's MES systems are relatively robust programs that allow companies to plan production resources, define and plan production processes, manage production itself, collect data related to production and allow it to perform various performance analyses, which, in fact, is close to production controlling. It is obvious that a system set up in this way must communicate with the ERP program on some basis. The point is that both systems need to share certain data, so most of the integration is set up to allow the sharing of key data. According to Kř́ž and Zajíc (2018), the integration of MES systems with ERP is currently one of the main trends in ERP development. However, the authors of the article no longer state in which specific details the integration takes place. One of the goals of further scientific research will be to find out in which areas integration takes place and whether there is a link to controlling. The research facilities will be large companies and major domestic suppliers of MES systems. The research will investigate what are the specific requirements of their customers - large manufacturing companies. It can be assumed that while large companies use data from MES systems for their controlling purposes (at least for production controlling and production quality controlling), the question is whether it is an isolated controlling within the MES system, or whether the data is transformed into ERP and there they are subsequently used for controlling purposes. Of course, a combination of both models is also possible.

With regard to the Internet of Things (IoT), as already mentioned in the second chapter, to meet the concept of Industry 4.0, the connected machine to the internet should not be a mere isolated connection of the machine. According to Mařik (2015), in this case it would be a certain higher form of automation, however not the Industry 4.0. In order to meet the concept, it would have to be part of a certain set of machines and production facilities that would share data with each other, and based on the data, production would be autonomously controlled, and the data also integrated into enterprise information systems. Further research will examine whether, or to what extent, machines and production equipment are integrated into corporate information systems. According to Kř́̌ž (2021), the Internet of Things currently has a security problem. According to the findings of Palo Alto Networks, up to $98 \%$ of all communication of the Internet of Things takes place without encryption (Kř́žz, 2021). The security of devices connected to the corporate network is a key issue, as these devices are generally more vulnerable. These facts may result in a slower rate of connection of IoT devices to corporate networks.

The researched IoT area may partially overlap with research in the field of MES systems integration, because the machine can be integrated into the company's MES system and then the data is transformed from MES to ERP and used for controlling. In the field of IoT, we will be more interested in a situation when the company does not directly have an MES system and the machine is integrated directly into the company's ERP. For large companies, this is not expected, but it cannot be ruled out.

The last area on which further research will focus is the integration of external applications with ERP systems and further use of this data for controlling. At this point, it does not make sense to describe the technical context of connecting external applications with ERP systems of companies. Basically, many software companies offer a variety of applications to streamline business processes. An example here is a simplified case study of SAP Concur. 
OF MANAGEMEI

IN THE $21^{\text {st }}$ CENTURY Vol. 16, No. 2, 2021

132

In 2014, SAP acquired Concur Technologies, which developed an application that enables businesses to effectively manage and control their travel expenses. SAP then fully integrated the application into its ERP system. The application works in principle as follows. If an employee goes on a business trip, the application allows him to manage all travel expenses related to the business trip in one place. For example, if he uses a taxi during a business trip or invites a business partner for lunch, he can simply scan the receipts he receives in this context using the mobile SAP Concur application he has installed on his mobile phone. The application is equipped with clever image reading technology and saves all the necessary data from the receipt (date, place, price without VAT, VAT, etc.) in a summary travel report. After returning from a business trip, during the processing of the travel report, the employee no longer has to copy data from receipts in a complicated way, he has them clearly arranged. As part of the processing of the report, the employee only confirms the data or he can add any other data into a report, for example the name of the business partner when required by local law or company processes. The application also uses Google Maps, so when a worker drives a car as part of a business trip, the application automatically measures and calculates the kilometres travelled. Once the work report is ready, the employee can send the report to his supervisor for approval. If the supervisor agrees with the report, the employee receives a notification from the application that his report has been accepted for processing. This basically ends the matter from the employee's point of view. Subsequently, the data from the travel report are transformed into ERP, where in essence there is an automatic posting to the relevant accounts. In SAP, expenses can be posted to the employee's internal SAP account (so-called Internal Orders), which is a subset of cost centre accounting. The application then allows managers to monitor actual travel expenses, or even compare them with planned expenses. The costs are monitored within the entire company, but they can be monitored also within individual departments.

In this case, the link to controlling is obvious. Therefore, further research will not examine whether companies can develop applications capable of integration with ERP with a subsequent link to controlling, but it will focus on specific and observable trends in this area. We will examine in which areas of business management the development of similar applications can be observed, what are the benefits for companies, and try to quantify the benefits and try to draw a general conclusion.

\section{Conclusions}

Companies currently operate in global and highly competitive markets. Even if the company wants to operate only in the local national market, thanks to the significant liberalization of international trade that has taken place in recent decades, it will equally be affected by international competition and events that are happening on other continents. Well-managed companies are aware of this situation, so they are increasingly applying a flexible management approach, which consists in constantly re-evaluating processes in order to maintain or increase the value of the company.

One of the tools available to companies in this context is controlling. The good news for companies is that thanks to Industry 4.0, controllers can use modern technologies for the purpose of data analysis, on the basis of which the company's management then makes operational or strategic decisions. The analysed data should therefore be correct in the first place, but also current and available. ERP systems are the central tools, especially for large companies, in which controlling is currently performed. These are a key source of data for controlling staff. The influence of Industry 4.0 on ERP systems is obvious, as today's robust ERP systems enable good availability and data sharing thanks to the cloud, but they are also equipped with advanced algorithms for the analysis of so-called "big data". Another way Industry 4.0 can help controlling is to integrate external applications and devices with ERP systems. In this context, the Internet of Things probably plays the most important role. 
The subject of further research will be the analysis of the degree of use of the above technologies for the purposes of controlling by large companies operating in the Czech Republic. The research will examine how large companies use new technologies for controlling purposes. Attention will be focused on individual areas of controlling that use new technologies the most. As part of the research, the researchers will quantify the benefits of introducing new technologies. Large companies will be examined in the research, because they usually make the biggest progress in implementing Industry 4.0. Our research will focus on large companies operating in the field of engineering industry, electrical industry, food industry and chemical industry. As already mentioned, the research will focus only on companies operating in the Czech Republic. The reason is the goal of the research which is to draw a general conclusion of the current state of the impact of new technologies on controlling in the Czech Republic. It would be possible to confront the results of research with similar research that was carried out abroad. In this sense, follow-up comprehensive research is offered which would compare the state of the impact of new technologies on controlling in individual countries or regions of the world.

\section{Acknowledgements}

This research has been carried out within the project 'Prediction Models in Finance SMEs' Specifics', ID number FP-S-20-6466, supported by the Internal Grant Agency of the Brno University of Technology.

\section{Declaration of Interest}

Authors declare no competing interest.

\section{References}

Biel, J. (2020). 50 critical ERP statistics: 2020 market trends, data and analysis. ORACLE NETSUITE. https://www.netsuite.com/portal/resource/articles/erp/erp-statistics.shtml

Častorál, Z. (2008). Strategický znalostní management a učici se organizace. [Strategic knowledge management and the learning organisations]. Vysoká škola finanční a správní. Eupress.

Ivanov, D., Tang, Ch., Dolgui, A., Battini, D., \& Das, A. (2021). Researchers' perspectives on Industry 4.0: Multi-disciplinary analysis and opportunities for operations management. International Journal of Production Research, 59(7), 2055-2078. https://doi.org/10.1080/00207543.2020.1798035

Faltejsková, O., \& Dvořáková, L. (2011). Vývoj požadavků na odborný a dovednostní profil controllera $\mathrm{v}$ kontextu globální ekonomické krize. [Development of requirements for the professional and skill profile of the controller in the context of the global economic crisis]. Trendy v podnikání. 1(1), 20-26.

Fatima, B., Sarah, A., \& Driss, A. (2020). The manufacturing executing system instead of ERP as shop floor management. In 13th International Colloquium of Logistics and Supply Chain Management, LOGISTIQUA., 2.-4.12.2020. Féz: Sidi Mohamed Ben Abdellah University. https://doi.org/10.1109/LOGISTIQUA49782.2020.9353907

Havlíček, K. (2011). Management \& controlling: malé a středni firmy. [Management \& controlling: small and medium businesses]. Vysoká škola finanční a správní. Eupress.

Jones, P., \& Burger, J. (2009). Configuring SAP ERP Financials and Controlling. Wiley Publishing.

Kašík, M. \& Havlíček, K. (2015). Marketing při utváření podnikové strategie. [Marketing: Part of a corporate strategy]. Vysoká škola finanční a správní. Eupress.

Kotler, P., \& Caslione, J. A. (2009). Chaotics: The business of managing and marketing in the age of turbulence. AMACOM.

Krř́ž, L., \& Zajíc, D. (2018). Trendy a inovace českého konzervativního trhu. [Trends and innovations in Czech conservative market]. ICT REVUE. https://ictrevue.ihned.cz/c3-66086870-0ICT00_d66086870-trendy-a-inovace-ceskeho-konzervativniho-trhu-erp

Kř́žž, L., (2021). Internet věcí má problém s bezpečností. [Internet of Things and its security issues]. ICT REVUE. https://archiv.hn.cz/c1-66970430-internet-veci-ma-problem-s-bezpecnosti

\begin{tabular}{l} 
PROBLEMS \\
OF MANAGEMENT \\
IN THE 21 $1^{\text {st }}$ CENTURY \\
Vol. 16, No. 2, 2021 \\
\hline 133
\end{tabular} 
Pavol ZAHORAN, Ondrej ZIZLAVSKY. Controlling in era of industry 4.0: opportunities for businesses in the field of the introduction of new technologies

OF MAN IN THE $21^{\text {st }}$ CENTURY Vol. 16, No. 2, 2021

134

Kutáč, J., \& Janovská, K. (2012). Podnikový controlling. [Corporate controlling]. Vysoká škola báňská Technická univerzita.

Lazar, J. (2012). Manažerské účetnictví a controlling. [Management accounting and Controlling]. Grada. Majstorovic, V., Stojadinovic, S., Lalic, B., \& Marjanovic, U. (2020). ERP in Industry 4.0 Context. In Lalic, B., Majstorovic, V., Marjanovic, U., Von Cieminski, G., \& Romero, D. (Eds.), Advances in production management systems. The Path to Digital Transformation and Innovation of Production Management Systems (pp. 287-294). Springer International Publishing. https://doi.org/10.1007/978-3-030-57993-7_33

Mař́k, V. (2015). Národní iniciativa Průmysl 4.0. [Industry 4.0 - the initiative for the Czech Republic]. Ministry of Industry and Trade. http://www.ppp4.cz/prezentace/documents/pdf/prumysl-4-0-brozurka.pdf

Papánek, P. (2015). Co musí umět skvělý controller z pohledu ředitele podniku. [Controller's skills from Managing Director perspective]. CAFINEWS. 3(2). 11-13.

Pisar, P., \& Mazo, M. E. (2020). Controlling, communication and corporate culture - the opportunity for SMEs. Economics and Sociology, 13(3), 113-132. https://doi.org/10.14254/2071-789X.2020/13-3/8

Psárska, M., Vochozka, M., \& Stehel, V. (2016). Controlling. Vysoká škola technická a ekonomická v Českých Budějovicích.

Sodomka, P., \& Klčová, H. Trendy na české ERP trhu a jeho aktuální vývoj. [Current development trends in Czech ERP market]. Systemonline. https://m.systemonline.cz/casopis-it-systems/kontakty.htm

Songyue, L., \& Shangyang, H. (2019). Three-dimensional Accounting Control Model under ERP Condition. In 2019 International Conference on Arts, Management, Education and Innovation (ICAMEI 2019). 12./14.1.2019. (pp. 114-118). Clausius Scientific.

Sönmez, A. (2014). Multinational Companies, Knowledge, and Technology Transfer. Springer.

Storm, M. (2018). Einflüsse von Industrie 4.0 und Digitalisierung auf das Controlling. Neue Herausforderungen für den Beruf des Controllers. [Influences of Industry 4.0 and digitalization on controlling. New challenges for the controlling profession]. Studylab.

Šoljaková, L. (2012). Aktuální požadavky na profesní kompetenci controllerů v České republice. [Current requirements for the professional competence of controllers in the Czech Republic]. Český finanční a účetní časopis, 7(4), 132-140.

Veber, J., \& Srpová, J. (2012). Podnikáni malé a střední firmy. [Management of small and medium-sized businesses]. Grada.

Zuzák, R., \& Fejfarová, M. (2009). Krizové řizení podniku. [Crisis management of business]. Grada.

Received: November 18, 2021

Accepted: December 14, 2021

Cite as: Zahoran, P., \& Zizlavsky, O. (2021). Controlling in era of industry 4.0: Opportunities for businesses in the field of the introduction of new technologies. Problems of Management in the $21^{\text {st }}$ Century, 16(2), 122-134. https://doi.org/10.33225/pmc/21.16.122

Pavol Zahoran

(Corresponding author)
PhD Student, Faculty of Business and Management, Brno University of Technology, Kolejni 2906/4, 61200 Brno, Czech Republic.

E-mail: Pavol.Zahoran@vutbr.cz

ORCID: https://orcid.org/0000-0003-0831-471X

Ondrej Zizlavsky
$\mathrm{PhD}$, Associate Professor, Faculty of Business and Management, Brno University of Technology, Kolejni 2906/4, 61200 Brno, Czech Republic.

E-mail: Ondrej.Zizlavsky@vut.cz

ORCID: https://orcid.org/0000-0001-8520-4747 